\title{
ANALISIS BERPIKIR KRITIS SISWA SMP DALAM MENYELESAIKAN SOAL PECAHAN DITINJAU DARI GAYA BELAJAR
}

\author{
Ayu Imamatul Muslimah', Didik Sugeng Pambudi², Ervin Oktavianingtyas ${ }^{2}$, \\ Hobri $^{2}$, Arif Fatahillah ${ }^{2}$ \\ Program Studi (S1) Pendidikan Matematika, FKIP, Universitas Jember (UNEJ) \\ Jalan Kalimantan 37 Kampus Tegalboto Jember 68121 \\ E-mail: ayumuslimah123@gmail.com
}

\begin{abstract}
In learning activities, one of the efforts that can be done to improve students' learning abilities is to support learning styles that are following the objectives so that learning can be done effectively. This research was conducted at Junior High School 1 Kalisat, located at Jl. Diponegoro 52 Kalisat, Jember. This study aims to describe the students' critical thinking processes in solving fraction problems in terms of visual, auditory and kinesthetic learning styles. Data collection techniques used consisted of learning style questionnaires, critical thinking tests, and interview method. The subjects in this study were 6 students consisting of 2 students who represented visual, auditory, and kinesthetic learning styles. Based on data analysis, the results show that students with a visual and kinesthetic learning style meet five indicators of critical thinking, namely basic clarification, basic skills, concluding, further clarification, and strategies and tactics. Students with auditory learning styles meet the four indicators of critical thinking namely basic clarification, building basic skills, further clarification, and concluding. While students with auditory learning styles are less able to meet the indicators of strategies and tactics.
\end{abstract}

Keywords: Critical Thinking, Learning Styles, Fraction Problems

\section{PENDAHULUAN}

Berpikir merupakan suatu aktivitas yang dilakukan otak untuk mengirim informasi ke seluruh tubuh. Berawal dari proses berpikir tersebut manusia dapat melakukan kegiatan fisik maupun nonfisik secara normal. Berpikir dapat diartikan sebagai pengetahuan awal yang dapat diperoleh dengan cara menghubungkan antara satu dengan yang lainnya baik berupa konsep, gagasan ataupun pengertian sehingga baru terbentuk suatu kesimpulan. Dengan berpikir orang memperoleh penemuan baru, setidak-tidaknya orang menjadi tahu tentang hubungan antar sesuatu. B. Clark dalam Azhari (2013) [1]. Dalam dunia pendidikan, proses berpikir siswa sangat penting dalam meningkatkan pengetahuannya terkait mempelajari suatu konsep maupun memecahkan suatu permasalahan. Belajar memecahkan suatu permasalahan, pada dasarnya merupakan belajar menggunakan metode-metode ilmiah atau berpikir secara sistematis, logis, teratur,

\footnotetext{
${ }^{1}$ Mahasiswa S-1 Prodi Pendidikan Matematika FKIP Universitas Jember

${ }^{2}$ Dosen Prodi Pendidikan Matematika FKIP Universitas Jember
} 
dan teliti. Tujuannya untuk memperoleh kemampuan dan kecakapan kognitif dalam memecahkan masalah secara rasional, lugas dan juga tuntas.

Setiap siswa memiliki kemampuan berpikir kritis yang berbeda pada setiap proses pembelajaran. Berpikir kritis adalah suatu kecakapan berpikir secara efektif yang dapat membantu seseorang untuk membuat, mengevaluasi, serta mengambil keputusan tentang apa yang diyakini atau dilakukan. [2]. Dalam penerapannya, kemampuan berpikir kritis siswa belum sepenuhnya terealisasi di institusi pendidikan yang ada. Pada penyelesaian masalah, siswa masih terbiasa menggunakan penyelesaian yang sama seperti apa yang telah diberikan oleh gurunya. Pelaksanaan pembelajaran di sekolah khususnya matematika semestinya tidak hanya sekadar menuntut siswa untuk menjawab soal dengan benar saja, namun perlu mendorong siswa agar memunculkan ide-ide baru [9]. Dalam hal ini, peran guru sangat diperlukan. Untuk meningkatkan kemampuan berpikir kritis siswa, salah satunya dapat dilakukan dengan menerapkan metode pembelajaran yang sesuai dengan karakteristik siswa yang dinamakan gaya belajar.

Gaya belajar adalah kombinasi dari bagaimana siswa menyerap dan kemudian mengatur serta mengolah informasi [3]. Kesesuaian gaya belajar merupakan kunci keberhasilan bagi seorang siswa dalam belajar. Oleh sebab itu, dalam kegiatan pembelajaran siswa sangat perlu dibantu dan diarahkan untuk mengenali gaya belajar yang sesuai dengan dirinya sehingga tujuan pembelajaran dapat tercapai secara efektif. Dalam hal ini, peran guru sangat diperlukan. Dengan mengetahui gaya belajar siswa, guru dapat mengarahkan mereka untuk belajar sesuai dengan gaya belajar yang mereka miliki sehingga dapat dengan mudah menerima pelajaran dan dapat meningkatkan hasil belajarnya [4]. Dalam penelitian ini dilakukan analisis berpikir kritis siswa dengan maksud untuk menyelidiki, menguraikan, dan menjabarkan proses berpikir kritis siswa dengan gaya belajar visual, auditorial, dan kinestetik. Adapun indikator berpikir kritis dapat dilihat pada Tabel 1 berikut.

Tabel 1. Indikator berpikir kritis

\begin{tabular}{|c|c|c|}
\hline No & Indikator & Sub Indikator \\
\hline \multirow{3}{*}{1} & \multirow{3}{*}{ Klarifikasi dasar } & Memfokuskan pertanyaan \\
\hline & & Menganalisis pertanyaan dan bertanya \\
\hline & & Menjawab pertanyaan \\
\hline \multirow{3}{*}{2} & \multirow{3}{*}{ Membangun keterampilan dasar } & Menilai kredibilitas sumber informasi \\
\hline & & $\begin{array}{l}\text { Mengamati dan menilai laporan hasil } \\
\text { observasi }\end{array}$ \\
\hline & & Membuat deduksi dan menilai deduksi \\
\hline
\end{tabular}




\begin{tabular}{cll}
\hline No & \multicolumn{1}{c}{ Indikator } & \multicolumn{1}{c}{ Sub Indikator } \\
\hline 3 & Menyimpulkan & Membuat induksi dan menilai induksi \\
\cline { 2 - 3 } & & Mengevaluasi \\
\hline 4 & Klarifikasi lebih lanjut & Mendefinisikan dan menilai definisi \\
& & Mengidentifikasi asumsi \\
\hline 5 & Mengatur strategi dan taktik & Menentukan suatu tindakan \\
& & Berinteraksi dengan orang lain \\
\hline
\end{tabular}

Sumber: Ennis (1996)

\section{METODE PENELITIAN}

Pada penelitian ini jenis yang digunakan adalah penelitian kualitatif dengan pendekatan deskriptif. Penelitian ini dilaksanakan di SMPN 1 Kalisat yang bertempat di J1. Diponegoro no. 52 Kecamatan Kalisat Kabupaten Jember. Subjek penelitian pada penelitian ini adalah Siswa kelas 7c SMPN 1 Kalisat sebanyak 6 siswa yang masingmasing merupakan perwakilan 2 siswa dari setiap tipe gaya belajar. Adapun tujuan penelitian ini adalah untuk mendeskripsikan dan menggambarkan proses berpikir kritis siswa dalam menyelesaikan masalah pecahan di SMPN 1 Kalisat secara terperinci. Metode analisis data yang digunakan adalah deskriptif kualitatif dengan pengumpulan data yaitu melalui angket gaya belajar, tes berpikir kritis, dan wawancara.

\section{HASIL PENELITIAN}

\section{Hasil Angket Gaya Belajar Siswa Kelas 7c}

Dari data yang diperoleh, terdapat kecenderungan pada suatu gaya belajar. Pada penelitian ini terdapat 5 kelompok kecenderungan gaya belajar yaitu visual (V), auditorial (A), kinestetik (K), campuran visual dan kinestetik (VK), serta campuran visual, auditorial, dan kinestetik (VAK). Untuk lebih jelasnya dapat dilihat pada Tabel 2 dan Gambar 1.

Tabel 2. Kecenderungan Gaya Belajar Kelas 7C SMPN 1 Kalisat

\begin{tabular}{|c|c|c|c|c|}
\hline Gaya Belajar & Frekuensi & Persentase & Skor Tertinggi & Kode \\
\hline \multirow[t]{2}{*}{$\mathrm{V}$} & 11 & $34 \%$ & 25 & $\mathrm{~V} 1$ \\
\hline & & & 25 & $\mathrm{~V} 2$ \\
\hline \multirow[t]{2}{*}{ A } & 5 & $16 \%$ & 24 & A1 \\
\hline & & & 23 & $\mathrm{~A} 2$ \\
\hline \multirow[t]{2}{*}{ K } & 9 & $28 \%$ & 24 & K1 \\
\hline & & & 26 & $\mathrm{~K} 2$ \\
\hline VA & 5 & $16 \%$ & & \\
\hline VAK & 2 & $6 \%$ & & \\
\hline
\end{tabular}




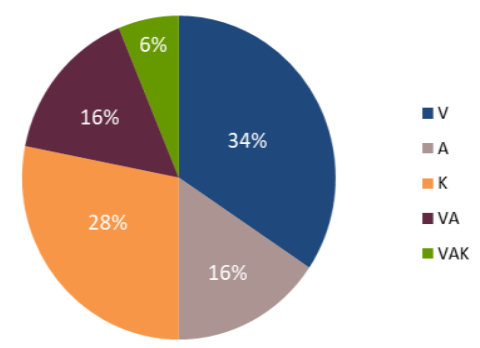

\section{Gambar 1. Diagram Persentase Kecenderungan Gaya Belajar Siswa Kelas 7C SMPN 1 Kalisat}

Hasil analisis gaya belajar pada siswa kelas 7c di SMPN 1 Kalisat menunjukkan sebanyak $34 \%$ siswa bertipe visual, $16 \%$ auditorial, $28 \%$ kinestetik, $16 \%$ campuran visual dan auditorial, dan 6\% campuran visual, auditorial dan kinestetik. Dengan demikian, gaya belajar yang mendominasi pada kelas 7c adalah gaya belajar visual yaitu sebesar $34 \%$.

\section{Analisis Proses Berpikir Kritis}

Berdasarkan hasil analisis hasil tes dan wawancara didapatkan hasil bahwa terdapat perbedaan proses berpikir kritis siswa yang kurang signifikan antara siswa bertipe gaya belajar visual, auditorial dan kinestetik. Adapun perbedaannya dapat dilihat pada Tabel 2.

Tabel 3. Hubungan Setiap Subjek dengan Indikator Berpikir Kritis

\begin{tabular}{ccccccc}
\hline \multirow{2}{*}{ Indikator Berpikir Kritis } & \multicolumn{7}{c}{ Subjek } \\
\cline { 2 - 7 } & V1 & V2 & A1 & A2 & K1 & K2 \\
\hline Klarifikasi dasar & $\checkmark$ & $\checkmark$ & $\checkmark$ & $\checkmark$ & $\checkmark$ & $\checkmark$ \\
\hline Membangun keterampilan dasar & $\checkmark$ & $\checkmark$ & $\checkmark$ & $\checkmark$ & $\checkmark$ & $\checkmark$ \\
\hline Menyimpulkan & $\checkmark$ & $\checkmark$ & $\checkmark$ & $\checkmark$ & $\checkmark$ & $\checkmark$ \\
\hline Klarifikasi lebih lanjut & $\checkmark$ & $\checkmark$ & $\checkmark$ & $\checkmark$ & $\checkmark$ & $\checkmark$ \\
\hline Mengatur strategi dan taktik & $\checkmark$ & $\checkmark$ & $\times$ & $\times$ & $\checkmark$ & $\checkmark$
\end{tabular}


Keterangan :

$\checkmark$ : memenuhi indikator berpikir kritis

$\times$ : tidak memenuhi indikator berpikir kritis

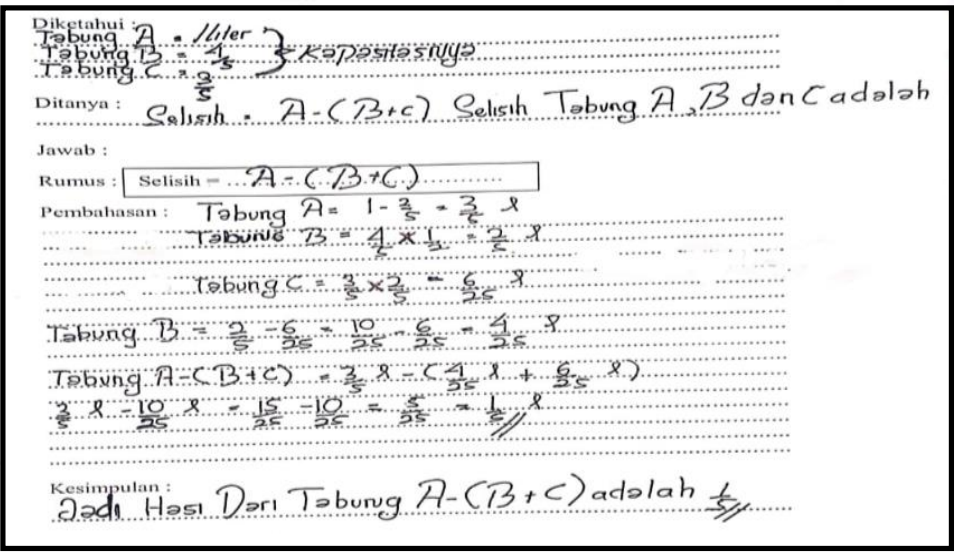

\section{Gambar 2. Pekerjaan Subjek Visual}

Pada indikator klarifikasi dasar, terdapat tiga sub indikator, yaitu memfokuskan pertanyaan, menganalisis pertanyaan, dan menjawab pertanyaan. Subjek dengan gaya belajar visual dapat memfokuskan pertanyaan dengan menuliskan informasi penting yang ada pada soal namun terdapat beberapa informasi yang tidak termuat di dalamnya, padahal informasi tersebut diberikan pada soal. Saat dilakukan wawancara, subjek visual dapat menjelaskan informasi apa saja yang terdapat pada soal. Hal ini sesuai dengan teori yang mengatakan bahwa seseorang dengan gaya belajar visual kadang-kadang kehilangan konsentrasi ketika mereka ingin memperhatikan sesuatu [3].

Ketika siswa dengan gaya belajar visual mulai fokus untuk mengerjakan soal, terkadang mereka kehilangan konsentrasi sehingga menyebabkan beberapa informasi tertinggal saat proses pengerjaan. Selain itu, pada saat membaca soal subjek visual cenderung membaca soal dengan cepat. Hal ini sesuai dengan teori yang menyebutkan bahwa ciri-ciri siswa dengan gaya belajar visual diantaranya adalah pembaca yang cepat [5]. Pada indikator klarifikasi dasar, subjek juga dapat menganalisis pertanyaan dengan menuliskan apa yang ditanyakan soal. Selain itu, subjek dengan gaya belajar visual juga dapat menjawab pertanyaan peneliti dengan baik saat dilakukan wawancara.

Oleh karena itu, pada indikator klarifikasi dasar subjek dengan gaya belajar visual memenuhi ketiga sub indikator yaitu memfokuskan pertanyaan, menganalisis pertanyaan, dan menjawab pertanyaan.

Pada indikator membangun keterampilan dasar, terdapat dua sub indikator, yaitu menilai kredibilitas sumber informasi serta mengamati dan menilai laporan hasil 
observasi. Kedua indikator ini dilihat berdasarkan kesinambungan antara hasil pekerjaan siswa dengan hasil tes wawancara. Dari hasil pekerjaannya, subjek visual dapat menerapkan beberapa operasi pecahan seperti penjumlahan, pengurangan, dan perkalian pecahan untuk menyelesaikan permasalahan pada soal. Subjek visual mampu menggali informasi pada soal dengan melakukan proses perhitungan tanpa menggambar sketsanya. Hal ini kurang sesuai dengan penelitian relevan yang mengemukakan bahwa siswa dengan gaya belajar visual mampu menggambarkan sketsa berdasarkan permasalahan yang ada pada soal [6].

Selain itu, subjek juga dapat menentukan rumus untuk menghitung selisih tabung $A$ dengan tabung $B$ dan $C$. Hal ini sesuai dengan penelitian relevan yang mengatakan bahwa siswa dengan gaya belajar visual melaksanakan langkah-langkah penyelesaian diawali dengan mengolah informasi yaitu mengaitkan data-data untuk menentukan rumus yang digunakan [7]. Selain itu, siswa dengan gaya belajar visual mampu mengekspresikan ide-ide yang dimilikinya dengan rapi dan teratur sesuai dengan pengetahuan yang dimilikinya dan informasi yang diperolehnya sehingga siswa mampu menyelesaikan dan menjawab permasalahan dengan sangat baik [6].

Dari hasil tes wawancara, ditunjukkan bahwa subjek visual memenuhi sub indikator menilai kredibilitas sumber informasi karena subjek dapat menjawab pertanyaan peneliti mengenai soal yang telah ia kerjakan. Selain itu, subjek juga dapat menilai laporan hasil observasi yang ditunjukkan ketika subjek ditanya mengenai cara ia mengolah informasi pada soal ia mampu menjelaskan. Oleh karena itu, pada indikator membangun keterampilan dasar subjek dengan gaya belajar visual memenuhi kedua sub indikator yaitu menilai kredibilitas sumber informasi serta mengamati dan menilai laporan hasil observasi.

Pada indikator menyimpulkan, terdapat tiga sub indikator, yaitu membuat deduksi dan menilai deduksi, membuat induksi dan menilai induksi, serta mengevaluasi. Subjek visual dapat membuat deduksi dan menilai deduksi yang dilihat dari hasil pekerjaan subjek dengan menggunakan rumus selisih yang sudah ia susun didapatkan hasil yang benar. Untuk sub indikator membuat induksi dan menilai induksi, subjek visual juga memenuhi sub indikator tersebut karena mereka menuliskan dan menyebutkan kesimpulan akhir dari permasalahan tersebut saat wawancara.

Pada indikator klarifikasi lebih lanjut, terdapat dua sub indikator yaitu mendefinisikan dan menilai definisi serta mengidentifikasi asumsi. Kedua indikator 
tersebut dilihat berdasarkan hasil tes wawancara. Berdasarkan hasil tes wawancara didapatkan bahwa subjek visual mampu mendefinisikan pecahan menurut sepemahamannya. Subjek visual menyebutkan bahwa pecahan menurutnya adalah bilangan yang terdiri dari pembilang dan penyebut. Ia juga menyebutkan contoh dari pecahan saja. Oleh karena itu, dapat dikatakan bahwa subjek visual memenuhi kedua sub indikator yaitu mendefinisikan dan menilai definisi serta mengidentifikasi asumsi.

Pada indikator mengatur strategi dan taktik, terdapat dua sub indikator yaitu menentukan suatu tindakan dan berinteraksi dengan orang lain. Pada sub indikator menentukan suatu tindakan, siswa dengan gaya belajar visual mampu mengerjakan soal dengan cukup runtut dan benar. Saat dilakukan wawancara, subjek juga dapat menjelaskan penyelesaian dengan cukup baik dengan mengaitkan informasi yang disediakan pada soal. Hal ini sesuai dengan penelitian relevan yang mengemukakan bahwa siswa dengan gaya belajar visual mampu mengambil data-data yang dianggap penting dan digunakan selama proses penyelesaian masalah [7]. Oleh karena itu, pada indikator ini, subjek visual memenuhi kedua indikator yaitu menentukan suatu tindakan dan berinteraksi dengan orang lain.

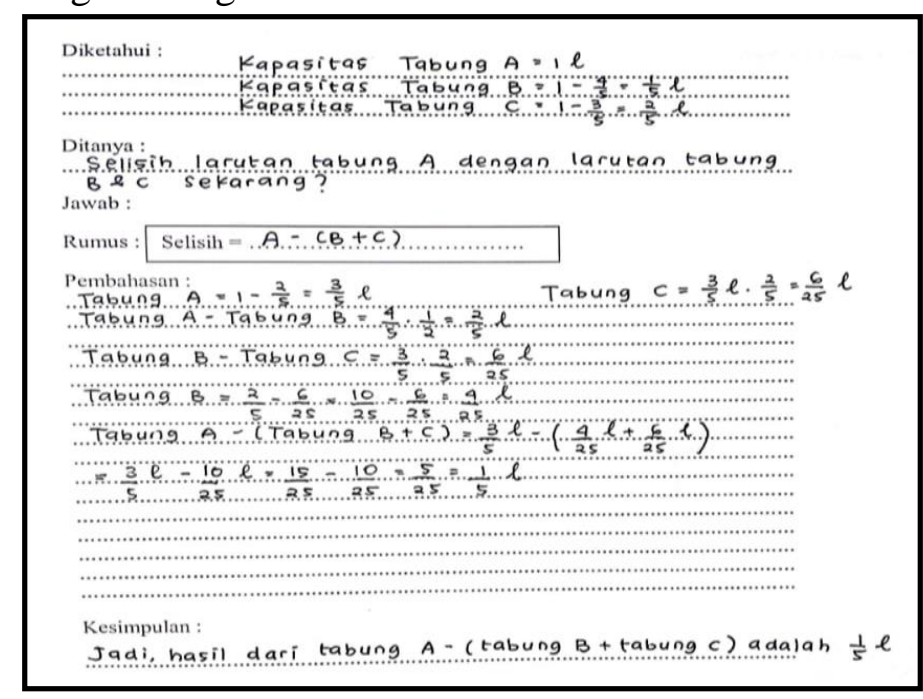

Gambar 3. Pekerjaan Subjek Auditorial

Pada indikator klarifikasi dasar, terdapat tiga sub indikator, yaitu memfokuskan pertanyaan, menganalisis pertanyaan, dan menjawab pertanyaan. Subjek dengan gaya belajar auditorial dapat memfokuskan pertanyaan dengan menuliskan informasi pada soal namun masih kurang lengkap. Terdapat beberapa informasi yang tidak ditulis pada lembar jawaban padahal informasi tersebut terdapat pada soal. Namun saat dilakukan wawancara, subjek dengan gaya belajar auditorial dapat menjawab pertanyaan peneliti 
terkait hasil pekerjaannya menjelaskan informasi apa saja yang terdapat pada soal. Hal ini sesuai dengan teori yang mengatakan bahwa seseorang dengan gaya belajar auditorial merasa kesulitan untuk menulis, tetapi hebat dalam bercerita [3]. Oleh karena itu, subjek dengan gaya belajar auditorial mampu menjelaskan informasi yang ada pada soal secara lengkap dan benar saat wawancara. Selain itu, subjek auditorial juga dapat menganalisis pertanyaan dengan menuliskan apa yang ditanyakan soal. Berdasarkan hasil tes dan wawancara dapat dikatakan bahwa subjek auditorial memenuhi ketiga sub indikator yaitu memfokuskan pertanyaan, menganalisis pertanyaan, dan menjawab pertanyaan.

Pada indikator membangun keterampilan dasar, terdapat dua sub indikator, yaitu menilai kredibilitas sumber informasi serta mengamati dan menilai laporan hasil observasi. Subjek auditorial dapat menilai kredibilitas sumber informasi dengan menjelaskan dan menjawab pertanyaan terkait hasil pekerjaannya. Selain itu, subjek juga dapat menilai laporan hasil observasi dengan menjelaskan informasi yang ia olah dalam menentukan penyelesaian, namun masih kurang lengkap karena beberapa informasi yang ada pada soal tidak dijelaskan. Hal ini sesuai dengan penelitian relevan yang mengemukakan bahwa siswa dengan gaya belajar auditorial dapat membuat rencana penyelesaian [7]. Oleh karena itu, dapat dikatakan bahwa pada indikator ini, subjek auditorial memenuhi kedua sub indikator yaitu menilai kredibilitas sumber informasi serta mengamati dan menilai laporan hasil observasi.

Pada indikator menyimpulkan, terdapat tiga sub indikator, yaitu membuat deduksi dan menilai deduksi, membuat induksi dan menilai induksi, serta mengevaluasi. Siswa auditorial dapat membuat dan menilai deduksi karena kedua subjek dapat menyelesaikan soal sehingga diperoleh hasil yang benar dengan menggunakan rumus yang telah ia tentukan berdasarkan soal. Hal ini sesuai dengan penelitian relevan yang mengatakan bahwa siswa dengan gaya belajar auditorial mampu mendefinisikan rumus-rumus matematika karena memang telah didiskusikan dan telah ia ketahui sebelumnya [6]. Selain itu, subjek auditorial juga dapat membuat dan menilai induksi dengan menuliskan kesimpulan akhir yang diperoleh berdasarkan hasil pekerjaannya. Subjek auditorial juga mengevaluasi jawaban yang telah didapat untuk meyakinkan kebenaran jawaban. Dari hasil tersebut dapat dikatakan bahwa subjek auditorial memenuhi ketiga sub indikator yaitu membuat deduksi dan menilai deduksi, membuat induksi dan menilai induksi, serta mengevaluasi. 
Pada indikator klarifikasi lebih lanjut, terdapat dua sub indikator yaitu mendefinisikan dan menilai definisi serta mengidentifikasi asumsi. Kedua indikator tersebut dilihat berdasarkan hasil tes wawancara. Subjek auditorial dapat menjelaskan definisi pecahan dengan menyebutkan bahwa pecahan merupakan suatu bilangan yang memiliki pembilang dan penyebut. Oleh karena itu, dapat dikatakan subjek auditorial memenuhi sub indikator mendefinisikan dan menilai definisi. Subjek dengan gaya belajar auditorial dapat menjelaskan definisi pecahan menurut sepamahamannya dengan lancar sehingga dapat dikatakan bahwa subjek auditorial dapat mengidentifikasi asumsi. Hal ini sesuai dengan teori yang mengatakan bahwa siswa dengan gaya belajar auditorial merasa kesulitan dalam menulis tetapi lebih hebat dalam bercerita [3].

Pada indikator mengatur strategi dan taktik, terdapat dua sub indikator yaitu menentukan suatu tindakan dan berinteraksi dengan orang lain. Pada sub indikator menentukan suatu tindakan, siswa auditorial dapat menyelesaikan soal namun terdapat beberapa kekekurangan seperti salah penulisan dan tidak dijelaskan langkah demu langkahnya. Selain itu, pada sub indikator berinteraksi dengan orang lain yang dilihat saat wawancara, subjek auditorial juga tidak mengingat beberapa hal yang telah ia kerjakan. Hal ini sejalan dengan penelitian relevan yang mengemukakan bahwa siswa dengan gaya belajar auditorial hanya mampu mengolah informasi dengan menunjukkan penggunaan rumus yang telah dituliskannya, tetapi kurang mampu menyimpan dan mengingat informasi selama proses perencanaan dan pelaksanaan penyelesaian [7]. Jadi, dapat dikatakan bahwa pada indikator ini, subjek dengan gaya belajar auditorial kurang memenuhi kedua sub indikator yaitu menentukan suatu tindakan dan berinteraksi dengan orang lain. 


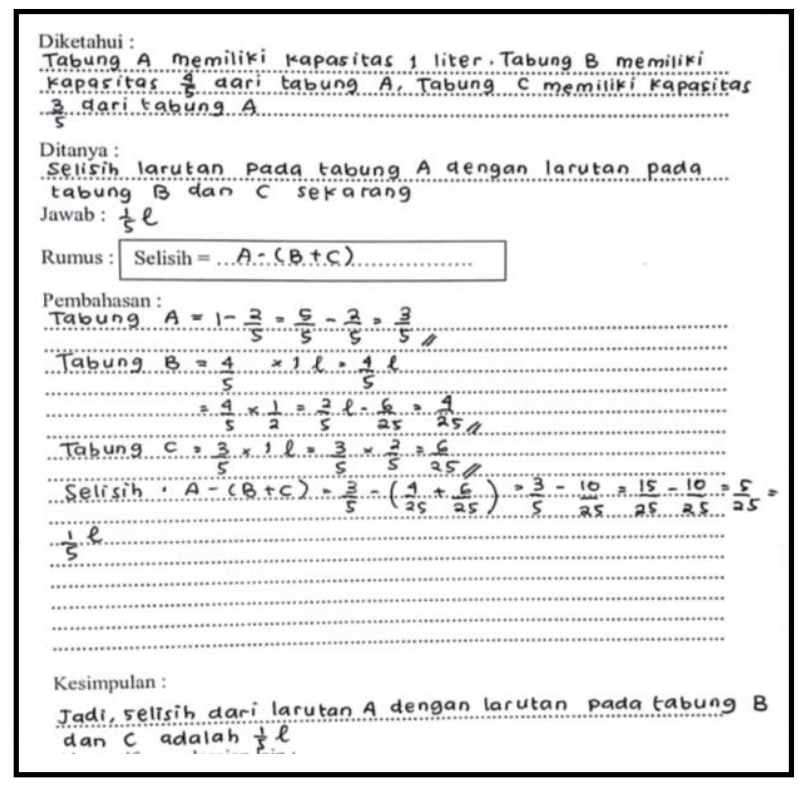

Gambar 4. Pekerjaan Subjek Kinestetik

Pada indikator klarifikasi dasar, terdapat tiga sub indikator, yaitu memfokuskan pertanyaan, menganalisis pertanyaan, dan menjawab pertanyaan. Pada sub indikator memfokuskan pertanyaan dan menganalisis pertanyaan, subjek kinestetik dapat menuliskan apa yang diketahui dan yang ditanyakan pada soal tetapi masih kurang lengkap. Namun, saat wawancara subjek kinestetik dapat menjawab pertanyaan dengan menyebutkan semua informasi yang diketahui pada soal secara lengkap. Hal ini sesuai dengan penelitian relevan yang mengatakan bahwa seseorang dengan gaya belajar kinestetik dalam proses berpikir kritis dalam memecahkan masalah mampu menuliskan apa yang diketahui dan yang ditanyakan soal [8]. Saat wawancara, subjek kinestetik menggunakan telunjuknya untuk membaca soal dan menyebutkan informasi apa saja yang terdapat pada soal. Hal ini sesuai dengan teori yang mengemukakan bahwa seseorang dengan gaya belajar kinestetik biasanya menggunakan jari sebagai penunjuk ketika membaca [3]. Berdasarkan hasil tes dan wawancara tersebut, dapat dikatakan bahwa subjek dengan gaya belajar kinestetik memenuhi ketiga sub indikator, yaitu memfokuskan pertanyaan, menganalisis pertanyaan, dan menjawab pertanyaan.

Pada indikator membangun keterampilan dasar, terdapat dua sub indikator, yaitu menilai kredibilitas sumber informasi serta mengamati dan menilai laporan hasil observasi. Kedua indikator ini dilihat berdasarkan kesinambungan antara hasil pekerjaan siswa dengan hasil tes wawancara. Subjek kinestetik mampu menjawab pertanyaan saat wawancara terkait hasil pekerjaannya dengan baik, sehingga dapat dikatakan bahwa subjek kinestetik memenuhi sub indikator menilai kredibilitas sumber informasi. Selain 
itu, subjek juga mampu menjelaskan bagaimana ia mengolah informasi yang didapat dari soal. Oleh karena itu, subjek kinestetik juga memenuhi sub indikator mengamati dan menilai laporan hasil observasi. Namun, subjek kinestetik hanya memiliki satu alternatif penyelesaian saja. Hal ini kurang sesuai dengan penelitian relevan yang mengatakan bahwa siswa dengan gaya belajar kinestetik dalam proses berpikir kritis mampu menyebutkan semua kemungkinan cara dan jawaban tepat yang dapat digunakan sehingga dapat menyelesaikan masalah dengan baik [8]. Berdasarkan hasil tes dan wawancara dapat dikatakan bahwa subjek dengan gaya belajar kinestetik memenuhi kedua sub indikator yaitu menilai kredibilitas sumber informasi serta mengamati dan menilai laporan hasil observasi.

Pada indikator menyimpulkan, terdapat tiga sub indikator, yaitu membuat deduksi dan menilai deduksi, membuat induksi dan menilai induksi, serta mengevaluasi. Berdasarkan hasil pekerjaannya, subjek kinestetik dapat menentukan rumus berdasarkan soal dan menyelesaikan soal dengan benar sehingga dapat dikatakan bahwa subjek kinestetik memenuhi sub indikator membuat dan menilai deduksi. Siswa kinestetik juga dapat menggeneralisasikan kesimpulan dari permasalahan yang diberikan dengan baik sehingga subjek kinestetik juga memenuhi sub indikator membuat dan menilai induksi. Selain itu, subjek kinestetik juga mengevaluasi kembali jawaban yang sudah diperoleh untuk

meyakinkan kebenaran jawabannya. Oleh sebab itu, didapatkan kesimpulan bahwa subjek dengan gaya belajar kinestetik memenuhi ketiga sub indikator yaitu membuat deduksi dan menilai deduksi, membuat induksi dan menilai induksi, serta mengevaluasi.

Pada indikator klarifikasi lebih lanjut terdapat dua sub indikator yaitu mendefinisikan dan menilai definisi serta mengidentifikasi asumsi. Kedua indikator tersebut dilihat berdasarkan hasil tes wawancara. Subjek dengan gaya belajar kinestetik dapat menjelaskan definisi pecahan menurut sepemahamannya. Hal ini ditunjukkan saat wawancara subjek menjelaskan bahwa pecahan merupakan suatu bilangan yang terdiri dari bilangan dan penyebut. Selain itu, subjek kinestetik juga memberikan contoh pecahan. Oleh karena itu, dapat dikatakan bahwa subjek kinestetik memenuhi kedua sub indikator yaitu mendefinisikan dan menilai definisi serta mengidentifikasi asumsi.

Pada indikator mengatur strategi dan taktik, terdapat dua sub indikator yaitu menentukan suatu tindakan dan berinteraksi dengan orang lain. Dalam menentukan suatu tindakan, subjek kinestetik dapat mengerjakan soal dengan langkah yang runtut dan benar 
dengan memanfaatkan beberapa operasi pecahan seperti penjumlahan, pengurangan, dan perkalian pecahan. Subjek kinestetik juga dapat menjelaskan dengan baik langkah pengerjaan soal yang sudah ditemukan saat wawancara sehingga dapat dikatakan bahwa subjek kinestetik memenuhi sub indikator berinteraksi dengan orang lain. Selain itu, subjek kinestetik juga mengevaluasi jawaban yang didapat sehingga diperoleh hasil yang tepat. Hal ini sesuai dengan penelitian relevan yang mengemukakan bahwa siswa dengan gaya belajar kinestetik mampu menunjukkan penggunaan rumus yang diterapkan, mampu menyimpan dan mengingat informasi dan melakukan pengecekan kembali pada proses perhitungan dan langkah-langkah yang diterapkan [7]. Berdasarkan hasil tes dan wawancara dapat dikatakan bahwa subjek dengan gaya belajar kinestetik memenuhi kedua sub indikator yaitu menentukan suatu tindakan dan berinteraksi dengan orang lain.

\section{KESIMPULAN}

Berdasarkan hasil analisis dan pembahasan yang diperoleh, dapat diketahui bahwa siswa dengan gaya belajar visual dan kinestetik memenuhi lima indikator berpikir kritis yaitu klarifikasi dasar, keterampilan dasar, menyimpulkan, klarifikasi lebih lanjut, serta strategi dan taktik. Siswa dengan gaya belajar auditorial memenuhi memenuhi empat indikator berpikir kritis yaitu klarifikasi dasar, membangun keterampilan dasar, klarifikasi lebih lanjut, dan menyimpulkan. Siswa auditorial kurang mampu memenuhi indikator mengatur strategi dan taktik dengan baik.

\section{DAFTAR PUSTAKA}

[1] Azhari \& Somakin. (2013). Peningkatan Kemampuan Berpikir Kreatif Matematik Siswa melalui Pendekatan Konstruktivisme di Kelas VII Sekolah Menengah Pertama (SMP) Negeri 2 Banyuasin III. Jurnal Pendidikan Matematika. 7(2): 1-12. https://doi.org/10.22342/jpm.8.1.992.1-12

[2] Jumaisyaroh, T., Napitupulu, E. E., \& Hasratuddin. Peningkatan Kemampuan Berpikir Kritis Matematis dan Kemandirian Belajar Siswa SMP melalui Pembelajaran Berbasis Masalah. Jurnal Kreano. 5(2): 157169. https://doi.org/10.15294/kreano.v5i2.3325

[3] DePorter, Bobbi \& Hernacki. (2010). Quantum Learning: Membiasakan Belajar Nyaman dan Menyenangkan. Bandung: Kaifa PT. Mizan Pustaka.

[4] Widiyanti, F. D. (2013). Pentingnya Mengetahui Gaya Belajar Siswa dalam Kegiatan Pembelajaran di Kelas. Erudio. 2(1): 8-20. https://erudio.ub.ac.id/index.php/erudio/article/view/228

[5] Sundayana, R. (2016). Kaitan Antara Gaya Belajar, Kemandirian Belajar, dan Kemampuan Pemecahan Masalah Siswa SMP dalam Pelajaran Matematika. Jurnal Mosharafa. 5(2): 75-84. https://doi.org/10.31980/mosharafa.v5i2.262 
[6] Mufida, M. (2015). Analisis Kemampuan Komunikasi Matematis pada Model PBL dengan Pendekatan Saintifik Berdasarkan Gaya Belajar Siswa Kelas VIII. Skripsi. Universitas Negeri Semarang.

[7] Tiffani, H. (2015). Profil Proses Berpikir Siswa SMP dalam Menyelesaikan Soal Perbandingan berdasarkan Gaya Belajar dan Gaya Kognitif. Jurnal Kependidikan Dasar. 1(1): 7-21.

[8] Amir, M. F. (2015). Proses Berpikir Kritis Siswa Sekolah Dasar dalam Memecahkan Masalah Berbentuk Soal Cerita Matematika Berdasarkan Gaya Belajar. Jurnal Math Educator Nusantara, 1(2): 159-170.

[9] Azizah, M., Sulianto, J., \& Cintang, N. 2018. Analisis Keterampilan Berpikir Kritis Siswa Sekolah Dasar pada Pembelajaran Matematika Kurikulum 2013. Jurnal Penelitian Pendidikan. 35(1): 61-70. 